\title{
Semi-continuous cultivation of the mixotrophic dinoflagellate Gymnodinium smaydae, a new promising microalga for omega-3 production
}

\author{
An Suk Lim ${ }^{1}$, Hae Jin Jeong ${ }^{2,3, *}$, Ji Hyun You ${ }^{2}$ and Sang Ah Park ${ }^{2}$ \\ ${ }^{1}$ Division of Life Science \& Plant Molecular Biology and Biotechnology Research Center, Gyeongsang National University, \\ Jinju 52828, Korea \\ ${ }^{2}$ School of Earth and Environmental Sciences, College of Natural Sciences, Seoul National University, Seoul 08826, Korea \\ ${ }^{3}$ Research Institute of Oceanography, Seoul National University, Seoul 08826, Korea
}

Omega-3 fatty acids, including eicosapentaenoic acid (EPA) and docosahexaenoic acid (DHA), are polyunsaturated fatty acids beneficial to human health. A limited number of microalgae have been used for commercial omega-3 production, which necessitates the identification of new microalgae with high omega-3 contents. We explored the fatty acid composition and EPA and DHA contents of the mixotrophic dinoflagellate Gymnodinium smaydae fed with the optimal algal prey species Heterocapsa rotundata. Cells of G. smaydae were found to be rich in omega-3 fatty acids. In particular, the DHA content of $G$. smaydae was $21 \mathrm{mg} \mathrm{g}^{-1}$ dry weight, accounting for $43 \%$ of the total fatty acid content. The percentage of DHA in the total fatty acid content of G. smaydae was the highest among the reported microalgae except for Crypthecodinium cohnii. Moreover, to determine if the prey supply interval affected the growth rate of G. smaydae and its fatty acid content, three different prey supply intervals (daily, once every $2 \mathrm{~d}$, and once for $4 \mathrm{~d}$ ) were tested. Daily prey supply yielded the highest total fatty acid and DHA contents in G. smaydae. Furthermore, we successfully produced high-density G. smaydae cultures semi-continuously for $43 \mathrm{~d}$ with daily prey supply. During the semi-continuous cultivation period, the highest density of $G$. smaydae was 57,000 cells $\mathrm{mL}^{-1}$, with an average growth rate of $0.7 \mathrm{~d}^{-1}$. Taken together, the percentage of EPA and DHA in the total fatty acid content was maintained in the range of 54.2-56.9\%. The results of this study support G. smaydae as a promising microalgal candidate for commercial DHA production and demonstrate that daily supply of prey can efficiently produce high-density G. smaydae cultures for more than a month.

Key Words: algae; biomass; DHA; EPA; FAME; lipid; polyunsaturated fatty acids

\section{INTRODUCTION}

Microalgae are typically phototrophic, unicellular species (Cuellar-Bermudez et al. 2015, Lim et al. 2019a). They are known to produce several useful biological materials, such as lipids, functional pigments, antioxidants, and bioactive compounds (Leu and Boussiba 2014, Cuellar-
Bermudez et al. 2015, Paliwal et al. 2017, Khan et al. 2018, Lim et al. 2018, Lee et al. 2019a, 2019b, Berthold et al. 2020). Thus, microalgae can be potentially used as food and energy resources for the future (Tan et al. 2015, Khan et al. 2018, Torres-Tiji et al. 2020). Omega-3 fatty acids, in-
(9) $\$$ This is an Open Access article distributed under the terms of the Creative Commons Attribution Non-Commercial License (http://creativecommons.org/licenses/by-nc/3.0/) which permits unrestricted non-commercial use, distribution, and reproduction in any medium, provided the original work is properly cited.
Received July 25, 2020, Accepted September 2, 2020

* Corresponding Author

E-mail: hjjeong@snu.ac.kr

Tel: +82-2-880-6746, Fax: +82-2-874-9695 
cluding eicosapentaenoic acid (EPA) and docosahexaenoic acid (DHA), are polyunsaturated fatty acids beneficial to human health (Gunstone 1996). The global market for microalgal products is estimated to be approximately US $\$ 6.5$ billion, of which DHA production accounts for US $\$ 1.5$ billion (Mobin and Alam 2017). DHA is essential for growth and functional development of the brain in infants and the maintenance of normal brain function in adults (Horrocks and Yeo 1999). Although fish oils represent the main dietary source of EPA and DHA, alternative sources of these omega-3 fatty acids are required owing to increasing marine pollution and depleting wild fish stocks (Doughman et al. 2007, Martins et al. 2013, Dhanya et al. 2020). Some marine protists are known to have high EPA and DHA contents; for example, the eustimatophyte Nannochloropsis spp. and the diatoms Phaeodactylum spp. and Odontella aurita have been identified as rich sources of EPA (Fajardo et al. 2007, Chua and Schenk 2017, Mobin and Alam 2017), whereas the thraustochytrids Thraustochytrium spp. and Schizochytrium spp. and the dinoflagellate Crypthecodinium spp. are rich sources of DHA (Jiang et al. 1999, Fan et al. 2007, Gupta et al. 2012). However, these constitute a very small portion of the formally described microalgae, and thus, further efforts are required to identify promising microalgal species containing high omega-3 contents.

In addition to high EPA and DHA contents, several other factors, such as ease of cultivation, high biomass productivity (or high growth rate), and lack of toxins, must be considered when culturing microalgae as a food source (Torres-Tiji et al. 2020). Even when a relatively fast-growing alga is selected for culture, the total production cost would increase if the cost for media or carbon sources is high. For example, glucose has been used as an effective organic compound to enhance the growth and production of some microalgae (Li et al. 2007, Cheirsilp and Torpee 2012); however, glucose is expensive, sometimes accounting for $80 \%$ of the total medium cost (Li et al. 2007). Therefore, to reduce the total production cost, low-cost nutrient and carbon sources and cost-effective culture methods should be developed. Several alternative compounds, such as sweet sorghum juice, Enteromorpha hydrolysate, and orange peel extract, have been tested to reduce the production cost (Liang et al. 2010, Park et al. 2018, Ning and Liu 2020). Providing dense prey cultures to mixotrophic dinoflagellates generally enhances their growth rate (Jeong et al. 2015). Thus, suitable algal prey cells present a good carbon source for mixotrophic microalgae with high growth rates and EPA or DHA contents. Based on this, it is beneficial to determine the op- timal cultivation conditions for maximum mixotrophic microalgal growth.

Dinoflagellates are one of the major microalgal groups and live in marine or freshwater environments (Taylor et al. 2008, Jeong et al. 2013, 2017, Kang et al. 2019). They exhibit all three trophic modes, i.e., autotrophy, heterotrophy, and mixotrophy (a combination of photosynthesis and phagotrophy) (Jeong et al. 2010, Stoecker et al. 2017, Lee et al. 2019b). Therefore, they play diverse roles as primary producers, predators, prey, symbiotic partners, and parasites in marine ecosystems (Jeong et al. 2010, 2015, Holmes et al. 2014, LaJeunesse et al. 2018). Several dinoflagellate species are known to contain diverse biological materials of economic importance, such as omega-3 fatty acids, macrolides, essential amino acids, carotenoids, and toxins (Shimizu 1996, Camacho et al. 2007, Mendes et al. 2009, Onodera et al. 2014, Jang et al. 2017, Lim et al. 2018). For example, the heterotrophic dinoflagellate Crypthecodinium cohnii is used for commercial DHA production (Mobin and Alam 2017). In addition, biotoxins produced by some phototrophic dinoflagellates, such as Prorocentrum concavum and Karenia bre$v i s$, are employed in the assessment of seafood safety and in medical and therapeutic studies (Camacho et al. 2007, Gallardo-Rodríguez et al. 2012, Assunção et al. 2017). Dinoflagellates have received significant attention as they contain various useful bioactive molecules and exhibit high biotechnological and pharmacological potential, and diverse culture methods have been employed to increase their biomass production across various industries (reviewed in Assunção et al. 2017). However, only a few species have been utilized for commercial production. The major obstacle in the large-scale culture of dinoflagellates for commercial use is their lower growth rates when compared with other microalgal groups (Tang 1996). Furthermore, dinoflagellates are more sensitive to turbulence than green algae and diatoms (Thomas and Gibson 1990). Therefore, identifying dinoflagellates containing useful biological materials and developing an effective method for their large-scale culture are critical for the commercial utilization of such dinoflagellates.

The dinoflagellate Gymnodinium smaydae, isolated from the waters of Shiwha Bay, Korea, was established as a new species in 2014 (Kang et al. 2014). This species was later revealed to be mixotrophic (Lee et al. 2014). This dinoflagellate grows rapidly when fed with the optimal algal prey species Heterocapsa rotundata but does not grow without added prey (Lee et al. 2014). This species exhibits considerable potential as a new microalga for commercial application. First, this species is one of 
the fastest growing mixotrophic dinoflagellates (Lee et al. 2014). Second, this species was found to be non-toxic in bioassays (Lim et al. 2018). Third, the optimal temperature and light intensity supporting maximum growth of this microalga have already been determined (You et al. 2020). Therefore, if this species contains high EPA or DHA contents, it can be a strong candidate for commercial omega-3 production.

In the present study, we analyzed the fatty acid composition and EPA and DHA contents of G. smaydae fed with $H$. rotundata using gas chromatography. The EPA and DHA contents were compared with reported contents of other microalgae. Moreover, to determine the optimal cultivation conditions supporting the high growth rate of G. smaydae, three different prey supply intervals were tested. To further test its suitability for commercial production, G. smaydae was cultured mixotrophically under optimized and controlled conditions for 43 days, and its fatty acid composition was analyzed. This study demonstrates G. smaydae as a strong candidate for the commercial production of omega- 3 fatty acids, its optimal culture conditions, and a new bioreactor design for mixotrophic dinoflagellates.

\section{MATERIALS AND METHODS}

\section{Culture of Gymnodinium smaydae and its prey species}

Cultures of G. smaydae (GSSH1005) and H. rotundata (HRSH1201) originally isolated from the waters of Shiwha Bay, Korea (Kang et al. 2014), were used in this study.

The specific growth rates of G. smaydae fed with $H$. rotundata were the highest at $25^{\circ} \mathrm{C}$, under $50 \mu \mathrm{mol}$ photon $\mathrm{m}^{-2} \mathrm{~s}^{-1}$ light-emitting diode (LED) illumination and 14 : 10-h light : dark cycle (You et al. 2020). Thus, experimental cultures were prepared under these conditions. Cells of G. smaydae cells (initial concentration: ca. 500 cells $\mathrm{mL}^{-1}$ ) were mixotrophically cultured in 2,000 - $\mathrm{mL}$ culture bottles with $H$. rotundata as the prey (ca. 50,000 cells $\mathrm{mL}^{-1}$ ) under the aforementioned water temperature and light conditions. A clonal culture of $H$. rotundata in $\mathrm{f} / 2$ medium (Merck, Germany) was also prepared under the same conditions.

\section{Cell harvesting}

The composition and contents of fatty acids of the cultured G. smaydae and H. rotundata were analyzed. Cells from dense G. smaydae cultures satiated with the prey and then starved for $1 \mathrm{~d}$ were harvested by centrifugation (Labogene 1696R; Gyrozen Co., Gimpo, Korea) at 4,315 ×g for $10 \mathrm{~min}$ and then stored at $-70^{\circ} \mathrm{C}$ in a deep freezer until analysis. To confirm the absence of any residual prey cells in the culture medium prior to cell harvest, a 5-mL aliquot was subsampled from each culture, fixed with acidic Lugol's solution, and then examined carefully under an inverted microscope.

\section{Effect of prey supply intervals on growth rate and fatty acid content of Gymnodinium smaydae}

The effect of different prey supply intervals during incubation for 4 d, i.e., supplied daily, once every $2 \mathrm{~d}$, and once for $4 \mathrm{~d}$, on the mixotrophic growth rate and fatty acid contents of G. smaydae was determined (Fig. 1).

Initial concentrations of G. smaydae and H. rotundata were established by transferring a predetermined volume of the culture with known cell density to the experimental bottles using an autopipette. Dense cultures of mixotrophic $G$. smaydae $\left(25,140\right.$ cells $\left.\mathrm{mL}^{-1}\right)$ fed with $H$. rotundata were transferred to nine 2,000-mL polycarbonate bottles containing $100 \mathrm{~mL}$ of $\mathrm{f} / 2$ medium. A dense $H$. rotundata culture $\left(255,500\right.$ cells $\left.\mathrm{mL}^{-1}\right)$ at the stationary stage was then added to the triplicate bottles at three different supply intervals as follows: $400 \mathrm{~mL}$ at the beginning of the experiment, i.e., prey supplied once for $4 \mathrm{~d} ; 200 \mathrm{~mL}$ at the beginning of the experiment and then again after 2 d, i.e., prey supplied every $2 \mathrm{~d}$; or $100 \mathrm{~mL}$ daily, i.e., prey supplied every day. The bottles were incubated at $25^{\circ} \mathrm{C}$ under $50 \mu \mathrm{mol}$ photons $\mathrm{m}^{-2} \mathrm{~s}^{-1}$ LED illumination and 14 : 10-h light : dark cycle. To determine the actual initial cell densities (cells $\mathrm{mL}^{-1}$ ) at the beginning of the experiment, 10 -mL aliquots were removed from each bottle and fixed with $5 \%$ acidic Lugol's solution. Moreover, to ensure that the final volume of each culture was the same at the end of the experiment, aliquots with the same total volume were removed from each bottle before and after every prey input, and fixed with 5\% acidic Lugol's solution. All or $>200$ G. smaydae cells were counted in three 1-mL Sedgwick-Rafter counting (SRC) chambers.

The specific growth rate of $G$. smaydae, $\mu\left(\mathrm{d}^{-1}\right)$, was calculated as follows:

$$
\mu=\frac{\operatorname{Ln}\left(\mathrm{C}_{\mathrm{t} 2} / \mathrm{C}_{\mathrm{t} 1}\right)}{\mathrm{t}_{2}-\mathrm{t}_{1}}
$$

, where $\mathrm{C}_{\mathrm{t} 1}$ and $\mathrm{C}_{\mathrm{t} 2}$ indicate cell concentrations at time points $t_{1}$ and $t_{2}$, respectively. The growth rates of G. smaydae were measured every day for $4 \mathrm{~d}$. 


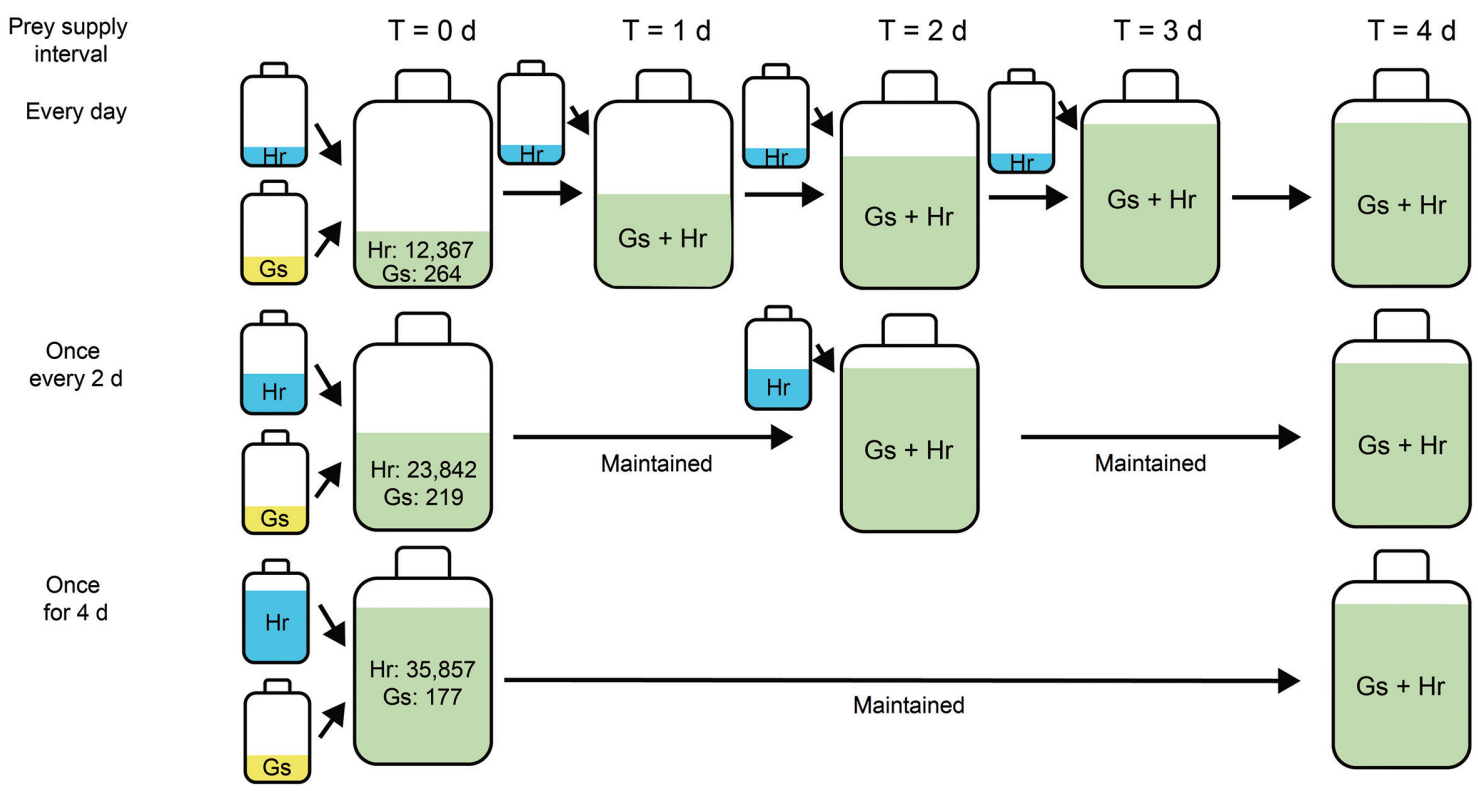

Fig. 1. Schematic representation of the experiment for studying the effect of different prey supply intervals during incubation for $4 \mathrm{~d}$, i.e., supplied daily, once every $2 \mathrm{~d}$, and once for $4 \mathrm{~d}$, on the mixotrophic growth rate and fatty acid contents of Gymnodinium smaydae. Culture volumes in the experimental bottles at $\mathrm{t}=0,1,2$, and $3 \mathrm{~d}$ under the three prey supply conditions were different, whereas those at $4 \mathrm{~d}$ were the same. Similar total volume of prey culture was added to the experimental bottles for $4 \mathrm{~d}$. $\mathrm{Hr}$, Heterocapsa rotundata; Gs, Gymnodinium smaydae. The numbers indicate the initial concentrations (cells $\mathrm{mL}^{-1}$ ) of $\mathrm{Hr}$ and Gs (see Materials and Methods section for details).

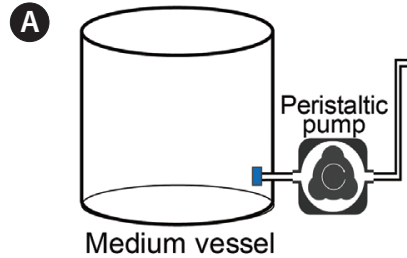

Medium vessel

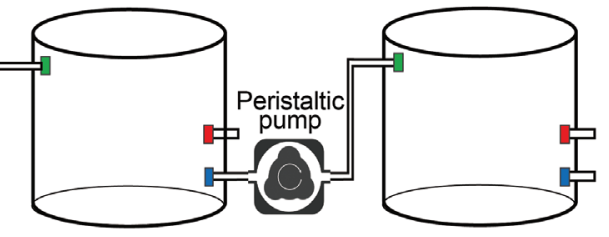

Prey culture vessel
Target culture vessel

B

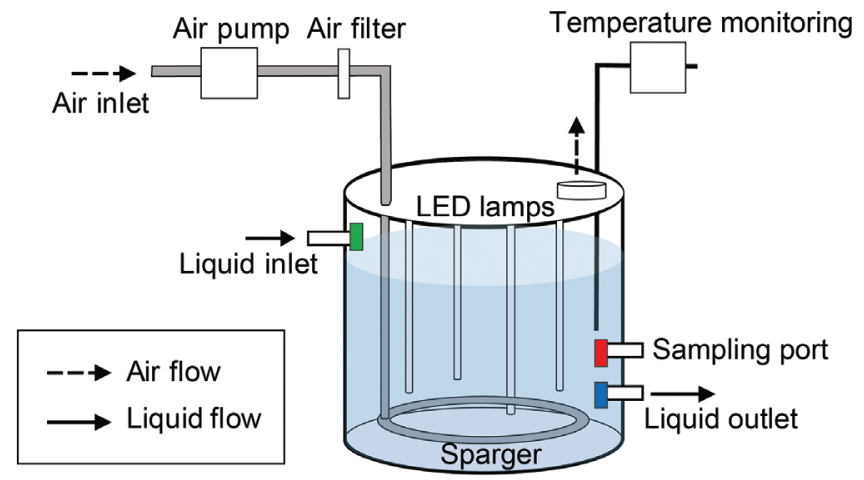

Fig. 2. Schematic diagram of an automatic system for culturing mixotrophic dinoflagellates (A) and the culture vessels (B) used in the present study. Media and cultures exiting the vessel through the liquid outlet were transferred to the next vessel through the liquid inlet. Air was supplied to the vessels using an air pump with an air filter for aeration and was dispersed evenly in the culture by the sparger (see Materials and Methods section for details). 
At the end of the experiment, i.e., after incubation for $4 \mathrm{~d}$, the bottles were further incubated under the same conditions for two more days to eliminate all prey cells from the G. smaydae cultures. Cells were harvested from the bottles as previously described, and the fatty acid composition and contents of G. smaydae grown under different prey supply intervals were analyzed.

\section{Semi-continuous cultivation of Gymnodinium smaydae}

Semi-continuous cultivation of G. smaydae was conducted to test its potential for application in EPA and DHA production. A newly developed photo-bioreactor for semi-continuous culturing of mixotrophic dinoflagellates was used for this experiment (Jeong and Lim 2020). The bioreactor consisted of three 10-L vessels, two peristaltic pumps, and silicon tubing (Masterflex, ColeParmer, IL, USA). Vessels containing the $\mathrm{f} / 2$ medium, prey, and predator were connected in series by the tubings. A peristaltic pump fed the $\mathrm{f} / 2$ medium into the prey vessel, and another pump fed the prey culture into the predator vessel (Fig. 2A). To avoid any potential countercurrent between the two vessels, the outlet nozzle of each vessel was designed to be positioned in the lower part of the vessel and the inlet nozzle was positioned in the upper part of the vessel (Fig. 2B). Filtered air was supplied into the vessel through a sparger for aeration, and was released via a hole in the lid of the vessel (Fig. 2B). LED lamps were fitted inside the vessel for illumination, and the temperature inside the vessel was continuously monitored (Fig. 2B).

The semi-continuous cultivation system was operated in a temperature-controlled chamber at $25 \pm 1^{\circ} \mathrm{C}$ under $50 \mu \mathrm{mol}$ photons $\mathrm{m}^{-2} \mathrm{~s}^{-1} \mathrm{LED}$ illumination and $14: 10-\mathrm{h}$ light : dark cycle, and the $\mathrm{f} / 2$ medium was also acclimated to this temperature. At the initial stage of operation, the medium vessel contained $10 \mathrm{~L}$ of fresh $\mathrm{f} / 2$ medium, the prey vessel contained $9 \mathrm{~L}$ of dense prey culture, and the predator vessel contained $3 \mathrm{~L}$ of dense G. smaydae culture. In this cultivation system, $H$. rotundata cultures in the prey vessel were automatically transferred to the $G$. smaydae culture vessel via a peristaltic pump (flow rate $=$ $300 \mathrm{~mL} \mathrm{~min}^{-1}$ ) for $10 \mathrm{~min}$. Thus, a total of $3 \mathrm{~L}$ of the prey culture was transferred to the G. smaydae culture vessel every day. When the volume in the G. smaydae culture vessel reached $9 \mathrm{~L}, 6 \mathrm{~L}$ of the culture was transferred to the container and starved for 1 day under the same conditions. After starvation, G. smaydae cells were harvested as previously described to analyze the fatty acid contents.
Simultaneously, $\mathrm{f} / 2$ medium from the medium vessel was transferred to the prey culture vessel using a peristaltic pump (flow rate $=2.1 \mathrm{~mL} \mathrm{~min}^{-1}$ ) in continuous operation. Thus, a total of $3 \mathrm{~L}$ of the $\mathrm{f} / 2$ medium was transferred to the prey vessel every day. Fresh f/2 medium was added into the medium vessel as required. The flow rates of all pumps were calibrated before use.

To monitor H. rotundata density in the prey vessel, the culture was homogenously and gently mixed by aeration through the sparger for $2 \mathrm{~min}$ (airflow rate $=1 \mathrm{~L} \mathrm{~min}^{-1}$ ) before subsampling (Fig. 2B). Ten milliliter aliquots were sampled daily from the prey vessel through a sampling port and fixed with 5\% acidic Lugol's solution. Moreover, to monitor G. smaydae and $H$. rotundata densities in the predator vessel, the culture was mixed as previously described, and 5-mL aliquots were subsampled before and after prey addition and fixed with 5\% acidic Lugol's solution. All or $>200$ cells of each species were counted in three 1-mL SRC chambers. The experiment continued for $43 \mathrm{~d}$, and the $\mathrm{pH}$ was not controlled.

\section{Lipid extraction and analysis}

To obtain dry biomass, frozen cell pellets were lyophilized using a freeze dryer (Bondiro, Ilshine, Dongducheon, Korea) at $-110^{\circ} \mathrm{C}$ under vacuum for $1 \mathrm{~d}$. Total fatty acid methyl esters (FAMEs) were analyzed in 2-39 mg samples, after extraction from the lyophilized cells using the one-step hydrolysis, extraction, and methylation procedure described by Garcés and Mancha (1993).

FAMEs were analyzed by gas chromatography (7890A; Agilent Technologies, Santa Clara, CA, USA). One microliter aliquots of the extracted FAMEs were injected into a capillary column (DB-23, Ser. No. US8897617H; $60 \mathrm{~m} \times$ $0.25 \mathrm{~mm}, 0.25 \mu \mathrm{m}$ film thickness) coupled with a flame ionization detector at a split ratio of $20: 1$. The temperature program was as follows: initial temperature $50^{\circ} \mathrm{C}$ maintained for $1 \mathrm{~min}$, increased to $130^{\circ} \mathrm{C}$ at $15^{\circ} \mathrm{C} \mathrm{min}^{-1}$, increased to $170^{\circ} \mathrm{C}$ at $8^{\circ} \mathrm{C} \mathrm{min}^{-1}$, increased to $215^{\circ} \mathrm{C}$ at $2^{\circ} \mathrm{C}$ $\mathrm{min}^{-1}$ and maintained for $10 \mathrm{~min}$. The injector and detector temperatures were $250^{\circ} \mathrm{C}$ and $280^{\circ} \mathrm{C}$, respectively. FAME peaks were identified by comparing the retention times of the samples with those of the reference standards (Supelco 37-component FAME mix; Supelco, Bellafonte, PA, USA). The fatty acid contents of G. smaydae and $H$. rotundata $(\mathrm{n}=3)$ were expressed as means of the triplicates, except for daily prey supply samples. 


\section{RESULTS}

\section{Lipid composition of Gymnodinium smaydae and Heterocapsa rotundata}

The total fatty acid (TFA) content of G. smaydae satiated with $H$. rotundata and then starved for $1 \mathrm{~d}$ was 49.46 $\mathrm{mg} \mathrm{g}^{-1}$. Of the detected fatty acids, DHA was the most dominant (21.22 $\mathrm{mg} \mathrm{g}^{-1}, 42.9 \%$ of TFAs), followed by palmitic acid (9.65 $\mathrm{mg} \mathrm{g}^{-1}, 19.5 \%$ of TFAs) and myristic acid (9.18 $\mathrm{mg} \mathrm{g}^{-1}, 18.6 \%$ of TFAs) (Table 1). The EPA content was $4.16 \mathrm{mg} \mathrm{g}^{-1}$ (8.4\% of TFAs), and the total omega-3 content was $25.63 \mathrm{mg} \mathrm{g}^{-1}$ (51.8\% of TFAs).
The TFA content of $H$. rotundata was $45.14 \mathrm{mg} \mathrm{g}^{-1}$. Of the detected fatty acids, palmitic acid was the most dominant (17.87 $\mathrm{mg} \mathrm{g}^{-1}, 39.6 \%$ of TFAs), followed by DHA (17.53 $\mathrm{mg} \mathrm{g}^{-1}, 38.8 \%$ of TFAs) and alpha-linolenic acid (3.23 $\mathrm{mg} \mathrm{g}^{-1}, 7.2 \%$ of TFAs) (Table 1). EPA and lignoceric acid were detected in G. smaydae but not in $H$. rotundata (Table 1).

\section{Specific growth rates and lipid composition of Gymnodinium smaydae at three different prey supply intervals}

The maximum specific growth rate of G. smaydae

Table 1. Contents ( $\mathrm{mg} \mathrm{g}^{-1}$ ) of fatty acids and their proportion (\%) in the total fatty acid content of the mixotrophic dinoflagellate Gymnodinium smaydae and its prey Heterocapsa rotundata

\begin{tabular}{|c|c|c|c|c|c|}
\hline \multirow{2}{*}{ Common name } & \multirow{2}{*}{$\begin{array}{c}\text { C:D } \\
\text { (carbon and } \\
\text { double number) }\end{array}$} & \multicolumn{2}{|c|}{ G. smaydae } & \multicolumn{2}{|c|}{ H. rotundata } \\
\hline & & Content & Percentage & Content & Percentage \\
\hline Butyric acid & $\mathrm{C} 4: 0$ & - & - & - & - \\
\hline Caproic acid & $\mathrm{C} 6: 0$ & - & - & - & - \\
\hline Caprylic acid & $\mathrm{C} 8: 0$ & - & - & - & - \\
\hline Capric acid & C10:0 & - & - & - & - \\
\hline Undecylic acid & C11:0 & - & - & - & - \\
\hline Lauric acid & $\mathrm{C} 12: 0$ & - & - & - & - \\
\hline Tridecylic acid & C13:0 & - & - & - & - \\
\hline Myristic acid & C14:0 & $9.18( \pm 0.02)$ & $18.58( \pm 0.54)$ & $2.45( \pm 0.02)$ & $5.42( \pm 0.01)$ \\
\hline Myristoleic acid & C14:1 & - & - & - & - \\
\hline Cis-10-pentadecenoic acid & C15:1 & - & - & - & - \\
\hline Palmitic acid & C16:0 & $9.65( \pm 0.06)$ & $19.53( \pm 0.40)$ & $17.87( \pm 0.10)$ & $39.60( \pm 0.15)$ \\
\hline Palmitoleic acid & C16:1 & - & - & - & - \\
\hline Margaric acid & C17:0 & - & - & - & - \\
\hline Cis-10-heptadecenoic acid & C17:1 & - & - & - & - \\
\hline Stearic acid & C18:0 & $0.70( \pm 0.03)$ & $1.41( \pm 0.02)$ & $1.22( \pm 0.00)$ & $2.71( \pm 0.03)$ \\
\hline Elaidic acid & C18:1n9t & - & - & - & - \\
\hline Oleic acid & C18:1n9c & $1.23( \pm 0.03)$ & $2.49( \pm 0.00)$ & $0.43( \pm 0.00)$ & $0.94( \pm 0.01)$ \\
\hline Linolelaidic acid & C18:2n6t & - & - & - & - \\
\hline Linoleic acid & C18:2n6c & $0.58( \pm 0.06)$ & $1.17( \pm 0.09)$ & $2.34( \pm 0.02)$ & $5.20( \pm 0.09)$ \\
\hline Gamma-linolenic acid & C18:3n6 & $0.22( \pm 0.01)$ & $0.44( \pm 0.01)$ & $0.06( \pm 0.00)$ & $0.14( \pm 0.00)$ \\
\hline Alpha-linolenic acid & C18:3n3 & $0.25( \pm 0.05)$ & $0.51( \pm 0.09)$ & $3.23( \pm 0.06)$ & $7.16( \pm 0.07)$ \\
\hline Arachidic acid & $\mathrm{C} 20: 0$ & - & - & - & - \\
\hline Eicosenoic acid & C20:1 & - & - & - & - \\
\hline Eicosadienoic acid & $\mathrm{C} 20: 2$ & - & - & - & - \\
\hline Dihomo-gamma-linolenic acid & C20:3n6 & - & - & - & - \\
\hline Heneicosylic acid & $\mathrm{C} 21: 0$ & - & - & - & - \\
\hline Arachidonic acid & $\mathrm{C} 20: 4 \mathrm{n} 6$ & - & - & - & - \\
\hline Eicosatrienoic acid & $\mathrm{C} 20: 3 \mathrm{n} 3$ & - & - & - & - \\
\hline Eicosapentaenoic acid & C20:5n3 & $4.16( \pm 0.27)$ & $8.41( \pm 0.32)$ & - & - \\
\hline Behenic acid & $\mathrm{C} 22: 0$ & - & - & - & - \\
\hline Erucic acid & $\mathrm{C} 22: \ln 9$ & - & - & - & - \\
\hline Docosadienoic acid & $\mathrm{C} 22: 2$ & - & - & - & - \\
\hline Tricosylic acid & $\mathrm{C} 23: 0$ & - & - & - & - \\
\hline Lignoceric acid & $\mathrm{C} 24: 0$ & $2.27( \pm 0.01)$ & $4.58( \pm 0.15)$ & - & - \\
\hline Docosahexaenoic acid & $\mathrm{C} 22: 6 \mathrm{n} 3$ & $21.22( \pm 0.85)$ & $42.88( \pm 0.57)$ & $17.53( \pm 0.26)$ & $38.83( \pm 0.23)$ \\
\hline Nervonic acid & $\mathrm{C} 24: 1$ & - & - & - & - \\
\hline Total fatty acids & - & $49.46( \pm 1.31)$ & - & $45.14( \pm 0.41)$ & - \\
\hline Total omega-3 & - & $25.63( \pm 1.16)$ & $51.79( \pm 0.98)$ & $20.76( \pm 0.32)$ & $46.00( \pm 0.29)$ \\
\hline Total omega- 6 & - & $0.80( \pm 0.07)$ & $1.61( \pm 0.10)$ & $2.41( \pm 0.02)$ & $5.34( \pm 0.10)$ \\
\hline Total omega-9 & - & $1.23( \pm 0.03)$ & $2.49( \pm 0.00)$ & $0.43( \pm 0.00)$ & $0.94( \pm 0.01)$ \\
\hline
\end{tabular}

All experiments were performed in triplicates, and data are expressed as means ( \pm standard error) of the three values. 


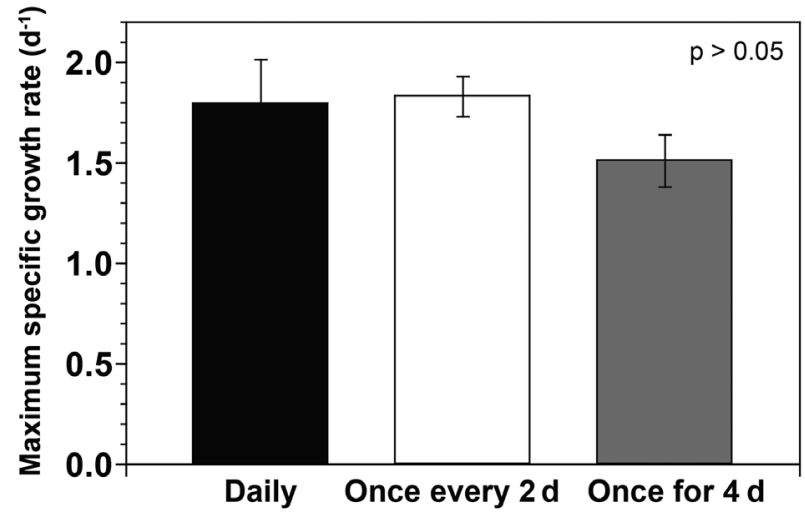

Fig. 3. Maximum specific growth rates $\left(d^{-1}\right)$ of Gymnodinium smaydae fed with Heterocapsa rotundata at different prey supply intervals during incubation for $4 \mathrm{~d}$ (supplied daily, once every $2 \mathrm{~d}$, and once for $4 \mathrm{~d}$ ). Symbols represent treatment means \pm standard error.

fed with $H$. rotundata at three different supply intervals ranged from 1.51-1.83 $\mathrm{d}^{-1}$ (Fig. 3). The maximum specific growth rate of $G$. smaydae fed with $H$. rotundata every day, once every $2 \mathrm{~d}$, and once for $4 \mathrm{~d}$ was $1.79,1.83$, and $1.51 \mathrm{~d}^{-1}$, respectively (Fig. 3). However, the prey supply interval did not significantly affect the maximum specific growth rate of G. smaydae (ANOVA, $\mathrm{F}_{(2,5)}=1.755, \mathrm{p}>0.05$ ).

The TFA and DHA contents in biomass dry weight of G. smaydae were significantly affected by the prey supply interval (ANOVA, $\mathrm{F}_{(2,5)}=7.381$ and $\mathrm{p}=0.032$ for TFAs, $\mathrm{F}_{(2,5)}=6.121$ and $\mathrm{p}=0.045$ for DHA). The TFA content of G. smaydae supplied daily with prey $\left(49.46 \mathrm{mg} \mathrm{g}^{-1}\right)$ was significantly higher than when prey was supplied every $2 \mathrm{~d}$ (37.98 $\mathrm{mg} \mathrm{g}^{-1}$; one-tailed t-test, $\mathrm{p}=0.005$ ) or once for

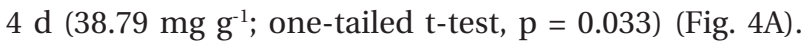
Similarly, the total omega-3 content of G. smaydae supplied daily with prey $\left(25.63 \mathrm{mg} \mathrm{g}^{-1}\right)$ was higher than when prey was supplied every $2 \mathrm{~d}\left(19.39 \mathrm{mg} \mathrm{g}^{-1}\right.$; one-tailed ttest, $\mathrm{p}=0.005)$ or once for $4 \mathrm{~d}\left(19.62 \mathrm{mg} \mathrm{g}^{-1}\right.$; one-tailed $\mathrm{t}$-test, $\mathrm{p}=0.043$ ) (Fig. 4A). Moreover, the DHA content of G. smaydae supplied daily with prey $\left(21.22 \mathrm{mg} \mathrm{g}^{-1}\right)$ was significantly higher than when prey was supplied every $2 \mathrm{~d}$ (16.21 $\mathrm{mg} \mathrm{g}^{-1}$; one-tailed t-test, $\left.\mathrm{p}=0.005\right)$ or once for

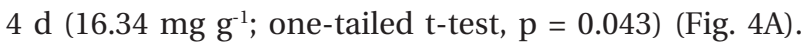
However, the EPA contents were not significantly different between the three prey supply intervals (ANOVA, $\mathrm{F}_{(2,}$, 5) $=4.001, \mathrm{p}>0.05$ ).

Furthermore, the proportion of EPA and DHA in the TFA content of G. smaydae was not significantly affected by the prey supply interval (ANOVA, $\mathrm{p}>0.05$ ) (Fig. 4B). Taken together, EPA and DHA accounted for more than $50 \%$ of G. smaydae TFAs under all three prey supply intervals (Fig. 4B).
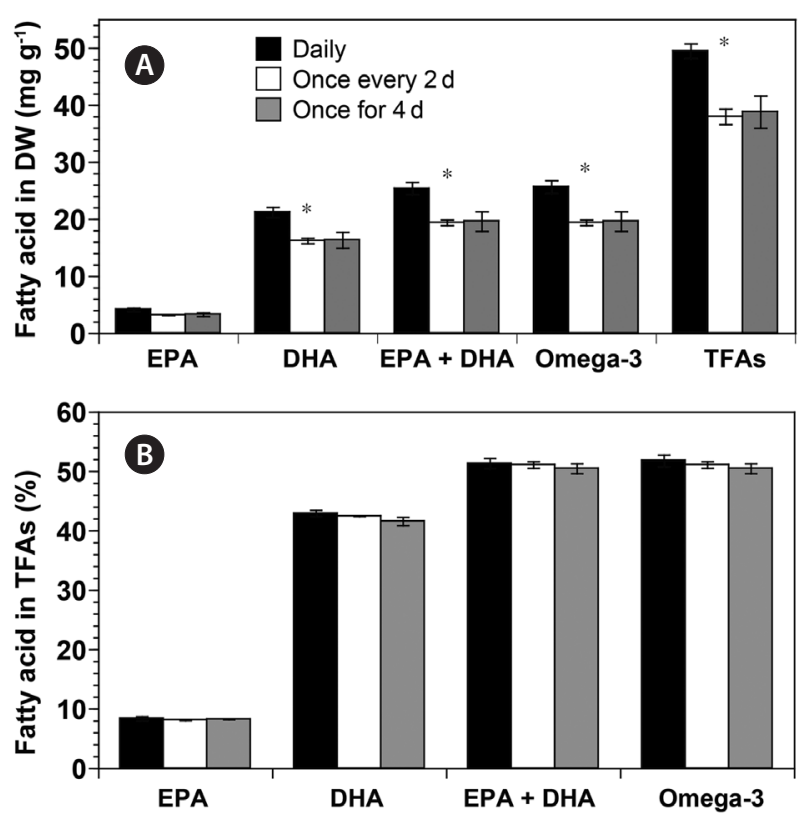

Fig. 4. Contents ( $\mathrm{mg} \mathrm{g}^{-1}$ ) of eicosapentaenoic acid (EPA), docosahexaenoic acid (DHA), EPA + DHA, omega-3, and total fatty acids (TFAs) in biomass dry weight (DW) (A) and percentage (\%) of EPA, DHA, EPA + DHA, and omega-3 in TFAs (B) of Gymnodinium smaydae fed with Heterocapsa rotundata at different prey supply intervals (daily, once every $2 \mathrm{~d}$, and once for $4 \mathrm{~d}$ ). Symbols represent treatment means \pm standard error. ${ }^{*} \mathrm{p}<0.05$.

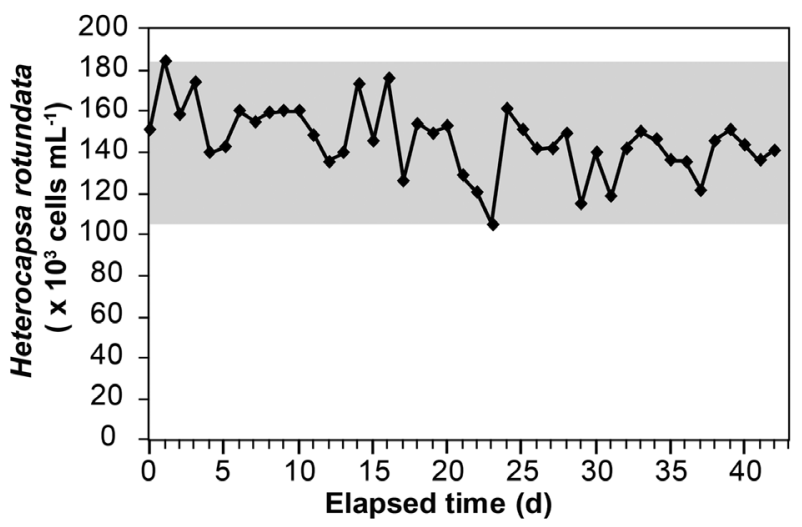

Fig. 5. Changes in Heterocapsa rotundata density (cells $\mathrm{mL}^{-1}$ ) in the prey culture vessel in the semi-continuous cultivation system over $43 \mathrm{~d}$. The gray area indicates the range of $\mathrm{H}$. rotundata density during the study period. Fresh medium was placed in the prey culture vessel at a continuous flow rate of $3 \mathrm{~L}$ per day.

\section{Semi-continuous cultivation of Gymnodinium smaydae}

Three liters (1/3 total volume) of the $H$. rotundata culture in the prey vessel were transferred to the G. smaydae culture vessel, to which $3 \mathrm{~L}$ of $\mathrm{f} / 2$ medium was added every day. The density of $H$. rotundata in the prey culture 

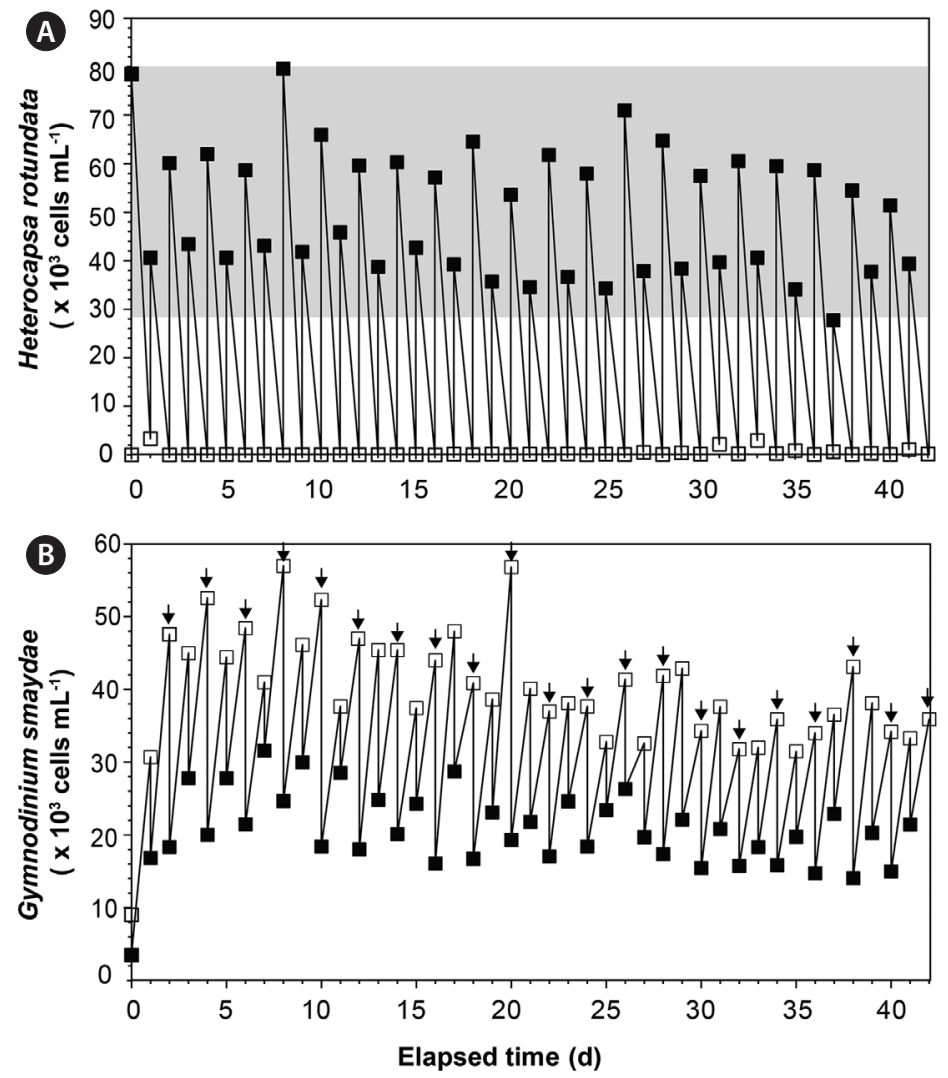

Fig. 6. Changes in the densities (cells $\mathrm{mL}^{-1}$ ) of Heterocapsa rotundata (A) and Gymnodinium smaydae (B) in the predator culture vessel of the semi-continuous cultivation system. The gray area in (A) indicates the range of $H$. rotundata density after feeding. An increase was observed in $H$. rotundata density owing to the daily addition of prey culture ( $3 \mathrm{~L}$ for $10 \mathrm{~min}$ ), which then decreased because of predation by $G$. smaydae (A). Arrows in (B) indicate the day when the G. smaydae culture was transferred to the harvest container. Dilution of the G. smaydae culture occurred because of daily addition of prey culture ( $3 \mathrm{~L}$ for $10 \mathrm{~min}$ ), but the density of $G$. smaydae increased after feeding on prey cells (B). Open and solid squares indicate the densities of $H$. rotundata and G. smaydae before and after prey culture addition, respectively.

vessel was maintained above 105,000 cells $\mathrm{mL}^{-1}$ (range: 105,333-184,667 cells $\mathrm{mL}^{-1}$ ) for $43 \mathrm{~d}$, although dilution due to the addition of $\mathrm{f} / 2$ medium was inevitable (Fig. 5). On transferring $3 \mathrm{~L}$ of the $H$. rotundata culture to the G. smaydae culture vessel, the former's density in the G. smaydae culture vessel increased (Fig. 6A). However, it decreased to almost zero with increasing incubation time because of predation by G. smaydae (Fig. 6A). After prey addition, the density of $H$. rotundata in the G. smaydae culture vessel was maintained between 27,750 and 79,600 cells $\mathrm{mL}^{-1}$ (Fig. 6A). Moreover, before prey addition, the density of G. smaydae in the G. smaydae culture vessel was maintained above 30,000 cells $\mathrm{mL}^{-1}$, except for the first day when G. smaydae was inoculated (Fig. 6B). The density of G. smaydae decreased temporarily immediately after prey addition, to as low as 3,500 cells $\mathrm{mL}^{-1}$ on the first day, before rapidly increasing to 30,700 cells $\mathrm{mL}^{-1}$ on the next day because of predation (Fig. 6B). The maximum density of G. smaydae in the vessel was recorded as 57,000 cells $\mathrm{mL}^{-1}$ (Fig. 6B), and the average growth rate of G. smaydae during the experimental period was $0.72 \mathrm{~d}^{-1}$. After starvation for 1 day, the density of $H$. rotundata in the $G$. smaydae culture vessels was $<10$ cells $\mathrm{mL}^{-1}$ for most samples, whereas the density of G. smaydae ranged from 29,363-43,500 cells $\mathrm{mL}^{-1}$.

In this semi-continuous cultivation system, the TFA content of G. smaydae in the harvested samples ranged from $52.80-65.24 \mathrm{mg} \mathrm{g}^{-1}$, whereas the DHA content ranged between 23.74-30.98 $\mathrm{mg} \mathrm{g}^{-1}$ (Fig. 7A \& B). Moreover, the content of EPA and DHA together was 28.67-37.15 $\mathrm{mg} \mathrm{g}^{-1}$ (Fig. 7C). DHA accounted for $45.0-47.5 \%$ of G. smaydae TFAs, averaging at $46.3 \%$, whereas EPA and DHA together accounted for $54.2-56.9 \%$ of the TFAs (Fig. 8). 

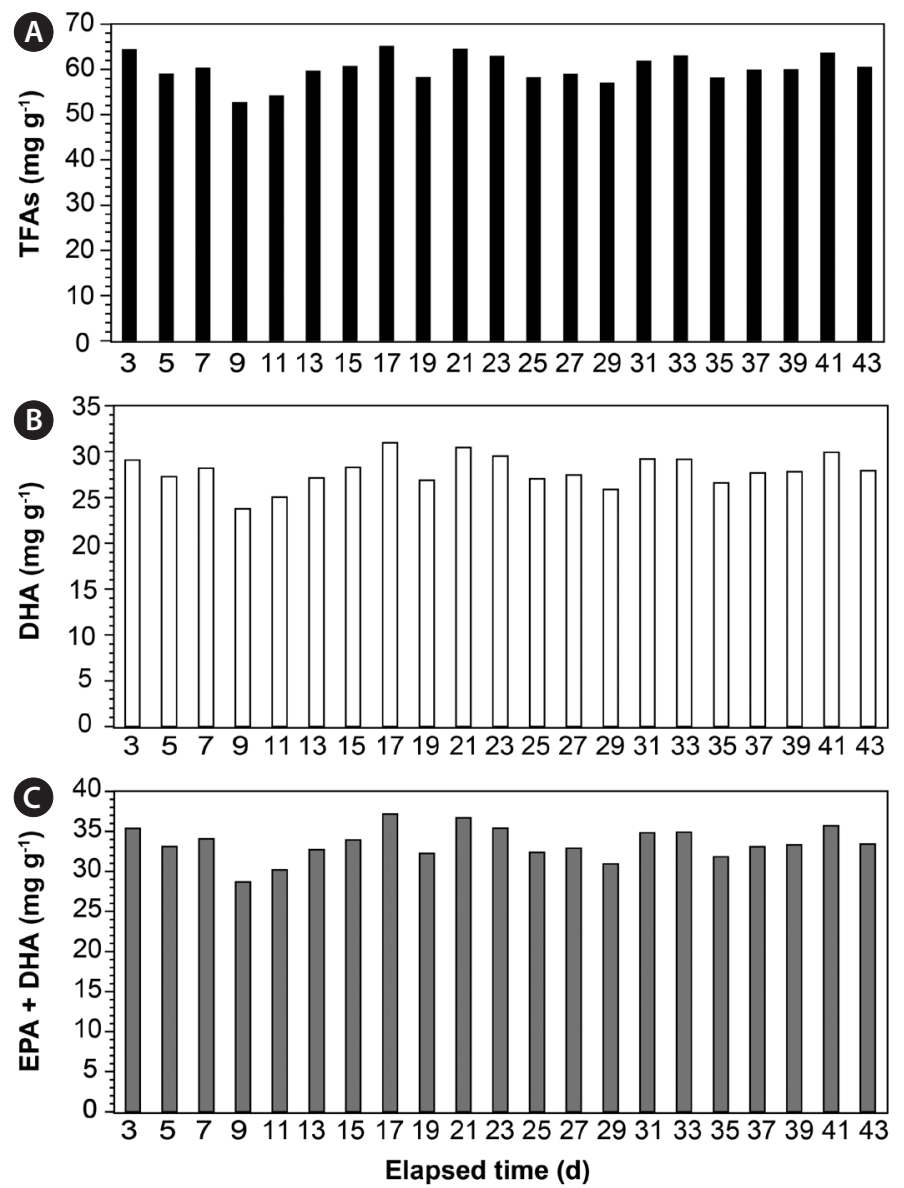

Fig. 7. Contents ( $\mathrm{mg} \mathrm{g}^{-1}$ ) of total fatty acids (TFAs) (A), docosahexaenoic acid (DHA) (B), and eicosapentaenoic acid (EPA) together with DHA (C) in Gymnodinium smaydae harvested using the semi-continuous cultivation system.
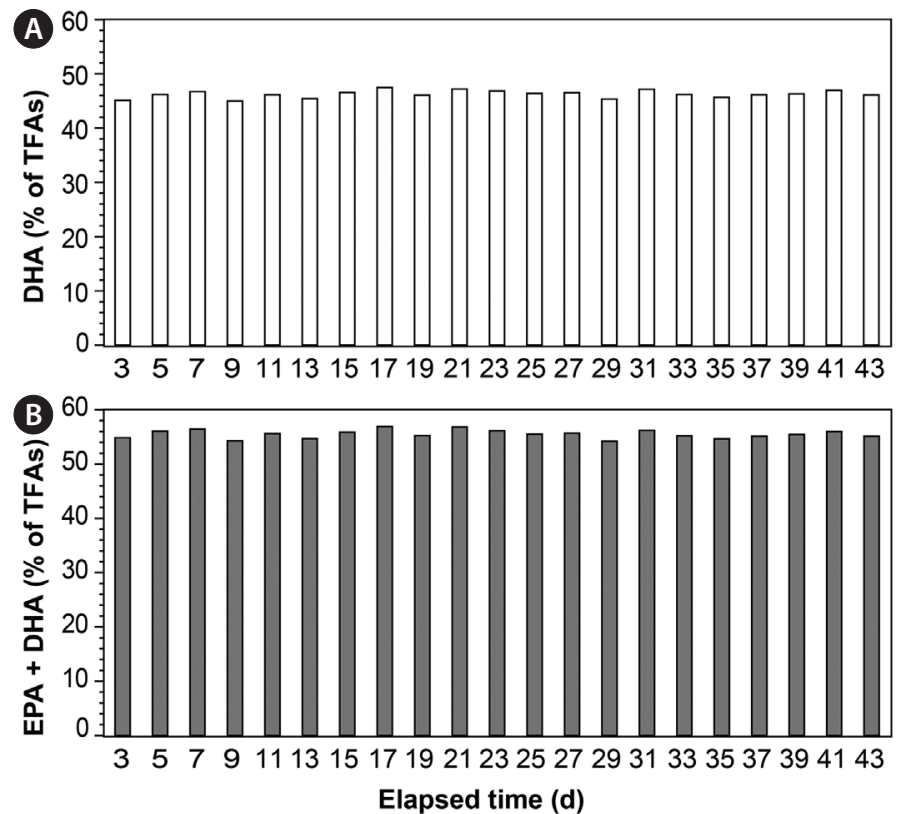

Fig. 8. Percentage (\%) of docosahexaenoic acid (DHA) (A) and eicosapentaenoic acid (EPA) together with DHA (B) in the total fatty acid (TFA) content of Gymnodinium smaydae harvested using the semi-continuous cultivation system. 

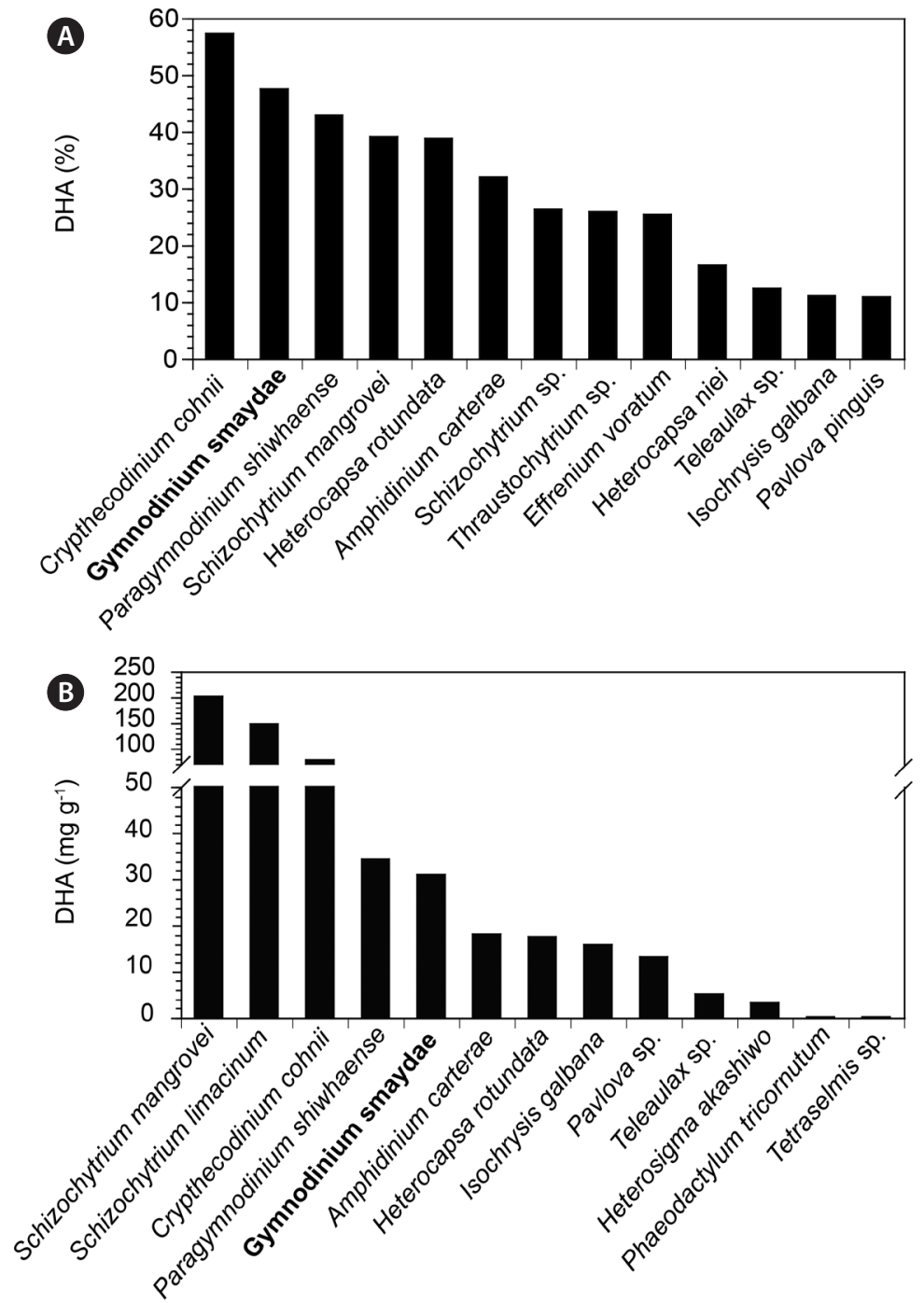

Fig. 9. Comparison of the percentage $(\%, A)$ of docosahexaenoic acid (DHA) in the total fatty acid content of Gymnodinium smaydae and other marine microalgae. Species exhibiting $>10 \%$ of DHA were included. Comparison of the DHA content (mg g $\left.{ }^{-1}, \mathrm{~B}\right)$ in biomass dry weight of G. smaydae and other marine microalgae. The values indicate the highest recorded DHA contents at $20-25^{\circ} \mathrm{C}$. G. smaydae is indicated in boldface. Data obtained from this study, Volkman et al. (1989), Dunstan et al. (1992), Thompson et al. (1992), Jiang et al. (1999, 2004), Jiang and Chen (2000), Mansour et al. (2005), Fan et al. (2007), Patil et al. (2007), Ethier et al. (2011), Jang et al. (2017), and Kang et al. (2020).

\section{DISCUSSION}

The present study demonstrated that G. smaydae fed with $H$. rotundata possess high DHA and omega-3 contents. Furthermore, a newly developed semi-continuous cultivation system could continuously produce dense $G$. smaydae cultures with high DHA and omega- 3 contents. The percentage of DHA in the TFA content of G. smaydae $(48 \%)$ was the highest among the reported microalgae, except for the commercially-used heterotrophic dinoflagellate C. cohnii (57\%) (Jiang et al. 1999, 2004, Jiang and
Chen 2000, Mansour et al. 2005, Jang et al. 2017), and was higher than that of the thraustochytrid Schizochytrium mangrovei (39\%) and the dinoflagellates Amphidinium carterae, $H$. rotundata, and Paragymnodinium shiwhaense (32-39\%). However, the absolute DHA content of G. smaydae fed with $H$. rotundata was lower than that of S. mangrovei, Schizochytrium limacinum, and $C$. cohnii but was comparable to that of P. shiwhaense (Table 2, Fig. 9). Therefore, G. smaydae is a good candidate for DHA production.

Several studies have been conducted to determine the 
Table 2. The percentage (\%) of eicosapentaenoic acid (EPA), docosahexaenoic acid (DHA), and EPA + DHA in the total fatty acid content of Gymnodinium smaydae and previously reported microalgae

\begin{tabular}{|c|c|c|c|c|c|c|c|}
\hline Species & Group & $\begin{array}{l}\text { EPA } \\
(\%)\end{array}$ & $\begin{array}{c}\text { DHA } \\
(\%)\end{array}$ & $\begin{array}{c}\mathrm{EPA}+\mathrm{DHA} \\
(\%)\end{array}$ & $\begin{array}{c}\text { Trophic } \\
\text { mode }\end{array}$ & $\begin{array}{c}\text { Carbon } \\
\text { source }\end{array}$ & Reference \\
\hline Amphidinium carterae & DINO & $23.9-32.9$ & $24.7-32.0$ & $48.6-64.9$ & A & - & $\begin{array}{l}\text { Jang et al. (2017), } \\
\text { Mansour et al. } \\
\text { (2005) }\end{array}$ \\
\hline Crypthecodinium cohnii & DINO & n.d & $40.5-57.3$ & $40.5-57.3$ & $\mathrm{H}$ & $\begin{array}{l}\text { Porphyridium } \\
\text { with glucose }\end{array}$ & $\begin{array}{l}\text { Jiang and Chen } \\
\text { (2000), Jiang et al. } \\
\text { (1999) }\end{array}$ \\
\hline Gymnodinium smaydae & DINO & $8.1-9.9$ & $41.6-47.5$ & $50.5-56.9$ & M & Microalgal prey & This study \\
\hline Paragymnodinium shiwhaense & DINO & $2.9-18.8$ & $30.5-42.9$ & $33.4-54.5$ & M & Microalgal prey & Jang et al. (2017) \\
\hline Schizochytrium mangrovei & THRA & $0.45-0.78$ & $32.3-39.1$ & $33.0-39.6$ & $\mathrm{H}$ & Glucose & Jiang et al. (2004) \\
\hline Phaeodactylum tricornutum & BACI & $10.1-39.0$ & $1.8-3.5$ & $11.9-39.0$ & A & - & $\begin{array}{l}\text { Yongmanitchai } \\
\text { and Ward (1991), } \\
\text { Thompson et al. } \\
\text { (1992) }\end{array}$ \\
\hline Heterocapsa rotundata & DINO & 0 & 38.8 & 38.8 & A & - & This study \\
\hline Teleaulax sp. & CRY & 25 & 12.4 & 37.4 & A & - & Jang et al. (2017) \\
\hline Effrenium voratum & DINO & 10.9 & 25.4 & 36.3 & A & - & Kang et al. (2020) \\
\hline Pavlova pinguis & HAP & 25.3 & 10.9 & 36.2 & A & - & Mansour et al. (2005) \\
\hline Heterosigma akashiwo & RAP & 27.1 & 3.4 & 30.6 & A & - & Jang et al. (2017) \\
\hline Pavlova lutheri & HAP & $7.9-19.7$ & $1.9-9.4$ & $9.8-29.1$ & A & - & $\begin{array}{l}\text { Volkman et al. (1989), } \\
\text { Thompson et al. } \\
\text { (1992) }\end{array}$ \\
\hline Schizochytrium sp. & THRA & $0.8-1.5$ & $15.6-26.3$ & $17.0-27.1$ & $\mathrm{H}$ & Glucose & Jiang et al. (2004) \\
\hline Rhodomonas salina & CRY & 17.6 & 8.9 & 26.5 & A & - & Mansour et al. (2005) \\
\hline Thraustochytrium sp. & THRA & $0.5-1.3$ & 18.9-25.9 & $20.1-26.4$ & $\mathrm{H}$ & Glucose & Jiang et al. (2004) \\
\hline Skeletonema sp. & BACI & 20.2 & 4.2 & 24.4 & A & - & Mansour et al. (2005) \\
\hline Thalassiosira pseudonana & BACI & $5.1-19.3$ & $1.1-3.9$ & $6.2-23.2$ & A & - & $\begin{array}{l}\text { Volkman et al. (1989), } \\
\text { Thompson et al. } \\
\text { (1992), Mansour et } \\
\text { al. (2005) }\end{array}$ \\
\hline Navicula jeffreyi & BACI & 20.1 & 2.1 & 22.2 & A & - & Mansour et al. (2005) \\
\hline Chroomonas salina & CRY & $10.9-11.9$ & $5.2-5.7$ & $16.6-17.1$ & A & - & Volkman et al. (1989) \\
\hline Heterocapsa niei & DINO & $<0.05$ & 16.5 & 16.6 & A & - & Mansour et al. (2005) \\
\hline Chaetoceros calcitrans & BACI & $10.5-14.6$ & $0.7-0.9$ & $11.2-15.5$ & A & - & $\begin{array}{l}\text { Volkman et al. (1989), } \\
\text { Thompson et al. } \\
\text { (1992) }\end{array}$ \\
\hline Isochrysis galbana & HAP & $0.6-1.9$ & $8.2-11.1$ & $10.1-11.7$ & A & - & $\begin{array}{l}\text { Thompson et al. } \\
\text { (1992) }\end{array}$ \\
\hline Micromonas pusilla & CHL & 0.3 & 8.5 & 8.8 & A & - & Dunstan et al. (1992) \\
\hline Proteomonas sulcata & CRY & 3.3 & 5.3 & 8.6 & A & - & Mansour et al. (2005) \\
\hline Isochrysis sp. & HAP & 0.2 & 8.3 & 8.5 & A & - & Volkman et al. (1989) \\
\hline Skeletonema costatum & BACI & 6 & 2.0 & 8.0 & A & - & Volkman et al. (1989) \\
\hline Tetraselmis chui & CHL & 8 & 0 & 8 & A & - & Dunstan et al. (1992) \\
\hline Chaetoceros simplex & BACI & $2-6.8$ & $0.5-1.2$ & $2.5-8.0$ & A & - & $\begin{array}{l}\text { Thompson et al. } \\
\text { (1992) }\end{array}$ \\
\hline Chaetoceros gracilis & BACI & $4.6-5.8$ & $0.3-0.6$ & $4.9-6.3$ & A & - & $\begin{array}{l}\text { Volkman et al. (1989), } \\
\text { Thompson et al. } \\
\text { (1992) }\end{array}$ \\
\hline Tetraselmis suecica & CHL & $4.3-5.3$ & TR & $4.3-5.3$ & A & - & Volkman et al. (1989) \\
\hline Pyramimonas cordata & CHL & 0.4 & 4.5 & 4.9 & A & - & Dunstan et al. (1992) \\
\hline Nannochloris atomus & CHL & 3.2 & $\mathrm{TR}$ & 3.2 & A & - & Volkman et al. (1989) \\
\hline Dunaliella tertiolecta & CHL & 0 & $0-0.6$ & $0-0.6$ & A & - & $\begin{array}{l}\text { Thompson et al. } \\
\text { (1992) }\end{array}$ \\
\hline
\end{tabular}

Only the data obtained at $20-25^{\circ} \mathrm{C}$ are presented.

DINO, Dinoflagellate; THRA, Thraustochytrids; BACl, Bacillariophyte (Diatom); CRY, Cryptophyceae; HAP, Haptophyta; RAP, Raphidophyceae; CHL, chlorophyte; n.d, no data; TR, trace amount; $A$, autotroph; $H$, heterotroph; $M$, mixotroph. 
optimal conditions to yield higher lipid content and biomass in commercial DHA production using microalgae (Jiang et al. 1999, 2004, Jiang and Chen 2000, Fan et al. 2007, Mendes et al. 2009, Liang et al. 2010, Martins et al. 2013). The DHA content of C. cohnii varies considerably under different cultivation conditions (21.5-77.9 $\left.\mathrm{mg} \mathrm{g}^{-1}\right)$ (Jiang et al. 1999, Pleissner and Eriksen 2012). Determining the optimal prey species, prey concentration, prey supply interval, and light and temperature conditions may be critical for increasing the cell density and culture volume of a target mixotrophic dinoflagellate. We previously identified the optimal prey species, prey concentration, and light and temperature for culturing G. smaydae (Lee et al. 2014, You et al. 2020). Providing a very dense prey culture in a single dose to a mixotrophic dinoflagellate may reduce labor and production costs. However, presence of prey cells in very high numbers sometimes reduces the growth rate of mixotrophic dinoflagellates (Kim et al. 2008, Blossom et al. 2012). Furthermore, remaining unutilized prey cells may deteriorate the culture water quality (Kim et al. 2008). Therefore, identifying the optimal prey supply interval under which G. smaydae exhibits a high growth rate and eliminates most prey cells is important. The results of the present study clearly show that the absolute DHA content of G. smaydae was significantly affected by the prey supply interval, although the maximum specific growth rate and the percentage of EPA and DHA in TFAs remained unaffected. Daily supply of prey cells to predator cultures is the most beneficial in the production of TFAs and DHA by G. smaydae. G. smaydae cells are likely to eliminate prey cells more effectively and produce more DHA when $H$. rotundata is supplied daily at a moderate concentration than when it is provided once every $2 \mathrm{~d}$ or once for $4 \mathrm{~d}$ at relatively higher concentrations.

Obtaining approximately $10 \mathrm{~L}$ of a pure microalgal culture is a critical step in omega-3 content, pigment, and transcriptome analyses. We successfully developed a 10-L culture system that could continuously produce healthy G. smaydae cultures for more than a month. The culture system was automatically operated and controlled for $43 \mathrm{~d}$ of the experimental period. The system design allowed for transferring a known volume of the prey culture from the prey vessel to the predator vessel, while adding the exact same volume of fresh medium to the prey culture vessel. This process was repeated 21 times. Therefore, using this system, dense G. smaydae cultures could be harvested every $2 \mathrm{~d}$. Based on the operation of culture systems producing $10 \mathrm{~L}$ of pure microalgal cultures, scaled-up culture systems capable of producing larger culture volumes for commercial DHA production can be developed. Obtaining sufficient quantities of seed culture $(20-25 \%$ of the final culture) for inoculation is a critical step in the scaling up process (Rawat et al. 2013).

This is the first study on semi-continuous cultivation of dinoflagellates using mixotrophy and an automatic system. Almost all previous studies on culturing dinoflagellates have focused on their autotrophic or heterotrophic growth (Jiang et al. 1999, Jiang and Chen 2000, Fuentes-Grünewald et al. 2016, Assunção et al. 2017). The effects of nutrients, light, and salinity on the growth and contents of compounds of interest in autotrophic dinoflagellate cultures have been investigated using phototrophic reactors (Camacho et al. 2007, GallardoRodríguez et al. 2007, 2010, Benstein et al. 2014, Wang et al. 2015, Fuentes-Grünewald et al. 2016). An automatic system has already been developed for culturing the heterotrophic dinoflagellate C. cohnii (De Swaaf et al. 2003). The growth rates and biomass of mixotrophic dinoflagellates are generally higher under mixotrophic conditions (i.e., with added prey) than under phototrophic conditions (i.e., without added prey) (Li et al. 1999, Jeong et al. 2015). Karlodinium veneficum and Effrenium voratum (previously Symbiodinium voratum) are known mixotrophic dinoflagellates, and their mixotrophic growth rates are considerably higher than their phototrophic growth rates (Li et al. 1999, Yoo et al. 2009, Jeong et al. 2012). Furthermore, the EPA content of $K$. veneficum fed with Storeatula major was greater than that of $K$. veneficum without added prey (Adolf et al. 2007). Thus, mixotrophy can be employed for higher production of biomass and biological materials by microalgae in comparison with autotrophy. Furthermore, mixotrophy may lower energy costs because dinoflagellates require lower light intensities for growth, as compared with when they are grown autotrophically (Li et al. 1999, Kim et al. 2008, Lim et al. 2019b). For culturing mixotrophic dinoflagellates, an arrangement for supplying prey is required to be added to a system for culturing autotrophic dinoflagellates. However, such an addition would be beneficial because mixotrophy yields considerably higher growth rates and biomass of mixotrophic dinoflagellates.

The present study presents the mixotrophic dinoflagellate G. smaydae as a new promising candidate microalga for commercial DHA production. Furthermore, the newly developed culture system for G. smaydae cells with daily prey supply can be used for designing largescale mass culture systems for omega-3 production by $G$. smaydae. 


\section{ACKNOWLEDGEMENTS}

This research was supported by the Useful Dinoflagellate program of Korea Institute of Marine Science and Technology Promotion (KIMST) funded by the Ministry of Oceans and Fisheries (MOF) and the National Research Foundation (NRF) funded by the Ministry of Science and ICT (NRF-2017R1E1A1A01074419) award to HJJ.

\section{REFERENCES}

Adolf, J. E., Place, A. R., Stoecker, D. K. \& Harding, L. W. Jr. 2007. Modulation of polyunsaturated fatty acids in mixotrophic Karlodinium veneficum (Dinophyceae) and its prey, Storeatula major (Cryptophyceae). J. Phycol. 43:1259-1270.

Assunção, J., Guedes, A. C. \& Malcata, F. X. 2017. Biotechnological and pharmacological applications of biotoxins and other bioactive molecules from dinoflagellates. Mar. Drugs 15:393.

Benstein, R. M., Çebi, Z., Podola, B. \& Melkonian, M. 2014. Immobilized growth of the peridinin-producing marine dinoflagellate Symbiodinium in a simple biofilm photobioreactor. Mar. Biotechnol. 16:621-628.

Berthold, D. E., de la Rosa, N., Engene, N., Jayachandran, K., Gantar, M., Laughinghouse, H. D. \& Shetty, K. G. 2020. Omega-7 producing alkaliphilic diatom Fistulifera sp. (Bacillariophyceae) from Lake Okeechobee, Florida. Algae 35:91-106.

Blossom, H. E., Daugbjerg, N. \& Hansen, P. J. 2012. Toxic mucus traps: a novel mechanism that mediates prey uptake in the mixotrophic dinoflagellate Alexandrium pseudogonyaulax. Harmful Algae 17:40-53.

Camacho, F. G., Rodríguez, J. G., Mirón, A. S., García, M. C. C., Belarbi, E. H., Chisti, Y. \& Grima, E. M. 2007. Biotechnological significance of toxic marine dinoflagellates. Biotechnol. Adv. 25:176-194.

Cheirsilp, B. \& Torpee, S. 2012. Enhanced growth and lipid production of microalgae under mixotrophic culture condition: effect of light intensity, glucose concentration and fed-batch cultivation. Bioresour. Technol. 110:510-516.

Chua, E. T. \& Schenk, P. M. 2017. A biorefinery for Nannochloropsis induction, harvesting, and extraction of EPArich oil and high-value protein. Bioresour. Technol. 244:1416-1424.

Cuellar-Bermudez, S. P., Aguilar-Hernandez, I., CardenasChavez, D. L., Ornelas-Soto, N., Romero-Ogawa, M. A. \& Parra-Saldivar, R. 2015. Extraction and purification of high-value metabolites from microalgae: essential lipids, astaxanthin and phycobiliproteins. Microb. Biotechnol. 8:190-209.

De Swaaf, M. E., Sijtsma, L. \& Pronk, J. T. 2003. High-celldensity fed-batch cultivation of the docosahexaenoic acid producing marine alga Crypthecodinium cohnii. Biotechnol. Bioeng. 81:666-672.

Dhanya, B. S., Sowmiya, G., Jeslin, J., Chamundeeswari, M. \& Verma, M. L. 2020. Algal biotechnology: a sustainable route for omega-3 fatty acid production. In Alam M. A., Xu, J. -L. \& Wang, Z. (Eds.) Microalgae Biotechnology for Food, Health and High Value Products. Springer, Singapore, pp. 125-145.

Doughman, S. D., Krupanidhi, S. \& Sanjeevi, C. B. 2007. Omega-3 fatty acids for nutrition and medicine: considering microalgae oil as a vegetarian source of EPA and DHA. Curr. Diabetes Rev. 3:198-203.

Dunstan, G. A., Volkman, J. K., Jeffrey, S. W. \& Barrett, S. M. 1992. Biochemical composition of microalgae from the green algal classes Chlorophyceae and Prasinophyceae. 2. Lipid classes and fatty acids. J. Exp. Mar. Biol. Ecol. 161:115-134.

Ethier, S., Woisard, K., Vaughan, D. \& Wen, Z. 2011. Continuous culture of the microalgae Schizochytrium limacinum on biodiesel-derived crude glycerol for producing docosahexaenoic acid. Bioresour. Technol. 102:88-93.

Fajardo, A. R., Cerdán, L. E., Medina, A. R., Fernández, F. G. A., Moreno, P. A. G. \& Grima, E. M. 2007. Lipid extraction from the microalga Phaeodactylum tricornutum. Eur. J. Lipid Sci. Technol. 109:120-126.

Fan, K. -W., Jiang, Y., Faan, Y. -W. \& Chen, F. 2007. Lipid characterization of mangrove thraustochytrid-Schizochytrium mangrovei. J. Agric. Food Chem. 55:2906-2910.

Fuentes-Grünewald, C., Bayliss, C., Fonlut, F. \& Chapuli, E. 2016. Long-term dinoflagellate culture performance in a commercial photobioreactor: Amphidinium carterae case. Bioresour. Technol. 218:533-540.

Gallardo-Rodríguez, J. J., García, M. D. C. C., Camacho, F. G., Mirón, A. S., Belarbi, E. H. \& Grima, E. M. 2007. New culture approaches for yessotoxin production from the dinoflagellate Protoceratium reticulatum. Biotechnol. Prog. 23:339-350.

Gallardo-Rodríguez, J. J. G., Mirón, A. S., Camacho, F. G., García, M. C. C., Belarbi, E. H. \& Grima, E. M. 2010. Culture of dinoflagellates in a fed-batch and continuous stirredtank photobioreactors: growth, oxidative stress and toxin production. Process Biochem. 45:660-666.

Gallardo-Rodríguez, J., Sánchez-Mirón, A., García-Camacho, F., López-Rosales, L., Chisti, Y. \& Molina-Grima, E. 2012. Bioactives from microalgal dinoflagellates. Biotechnol. 
Adv. 30:1673-1684.

Garcés, R. \& Mancha, M. 1993. One-step lipid extraction and fatty acid methyl esters preparation from fresh plant tissues. Anal. Biochem. 211:139-143.

Gunstone, F. D. 1996. Fatty acid and lipid chemistry. Blackie Academic, London, 263 pp.

Gupta, A., Barrow, C. J. \& Puri, M. 2012. Omega-3 biotechnology: thraustochytrids as a novel source of omega-3 oils. Biotechnol. Adv. 30:1733-1745.

Holmes, M. J., Brust, A. \& Lewis, R. J. 2014. Dinoflagellate toxins: an overview. In Botana, L. M. (Ed.) Seafood and Freshwater Toxins: Pharmacology, Physiology, and Detection. 3rd ed. CRC Press, Boca Raton, FL, pp. 3-38.

Horrocks, L. A. \& Yeo, Y. K. 1999. Health benefits of docosahexaenoic acid (DHA). Pharmacol. Res. 40:211-225.

Jang, S. H., Jeong, H. J. \& Kwon, J. E. 2017. High contents of eicosapentaenoic acid and docosahexaenoic acid in the mixotrophic dinoflagellate Paragymnodinium shiwhaense and identification of putative omega-3 biosynthetic genes. Algal Res. 25:525-537.

Jeong, H. J. \& Lim, A. S. 2020. Method and system for continuous mass culture for mixotrophic dinoflagellates. Patent no. KR102064718B1. Korean Intellectual Property Office, Daejeon.

Jeong, H. J., Lim, A. S., Franks, P. J. S., Lee, K. H., Kim, J. H., Kang, N. S., Lee, M. J., Jang, S. H., Lee, S. Y., Yoon, E. Y., Park, J. Y., Yoo, Y. D., Seong, K. A., Kwon, J. E. \& Jang, T. Y. 2015. A hierarchy of conceptual models of red-tide generation: nutrition, behavior, and biological interactions. Harmful Algae 47:97-115.

Jeong, H. J., Lim, A. S., Lee, K., Lee, M. J., Seong, K. A., Kang, N. S., Jang, S. H., Lee, K. H., Lee, S. Y., Kim, M. O., Kim, J. H., Kwon, J. E., Kang, H. C., Kim, J. S., Yih, W., Shin, K., Jang, P. K., Ryu, J. -H., Kim, S. Y., Park, J. Y. \& Kim, K. Y. 2017. Ichthyotoxic Cochlodinium polykrikoides red tides offshore in the South Sea, Korea in 2014: I. Temporal variations in three-dimensional distributions of red-tide organisms and environmental factors. Algae 32:101-130.

Jeong, H. J., Yoo, Y. D., Kang, N. S., Lim, A. S., Seong, K. A., Lee, S. Y., Lee, M. J., Lee, K. H., Kim, H. S., Shin, W., Nam, S. W., Yih, W. \& Lee, K. 2012. Heterotrophic feeding as a newly identified survival strategy of the dinoflagellate Symbiodinium. Proc. Natl. Acad. Sci. U. S. A. 109:12604-12609.

Jeong, H. J., Yoo, Y. D., Kim, J. S., Seong, K. A., Kang, N. S. \& Kim, T. H. 2010. Growth, feeding, and ecological roles of the mixotrophic and heterotrophic dinoflagellates in marine planktonic food webs. Ocean Sci. J. 45:65-91.

Jeong, H. J., Yoo, Y. D., Lee, K. H., Kim, T. H., Seong, K. A., Kang, N. S., Lee, S. Y., Kim, J. S., Kim, S. \& Yih, W. H.
2013. Red tides in Masan Bay, Korea in 2004-2005: I. Daily variations in the abundance of red-tide organisms and environmental factors. Harmful Algae 30S(Suppl. 1):S75-S88.

Jiang, Y. \& Chen, F. 2000. Effects of temperature and temperature shift on docosahexaenoic acid production by the marine microalge Crypthecodinium cohnii. J. Am. Oil Chem. Soc. 77:613-617.

Jiang, Y., Chen, F. \& Liang, S. -Z. 1999. Production potential of docosahexaenoic acid by the heterotrophic marine dinoflagellate Crypthecodinium cohnii. Process Biochem. 34:633-637.

Jiang, Y., Fan, K. -W., Tsz-Yeung Wong, R. \& Chen, F. 2004. Fatty acid composition and squalene content of the marine microalga Schizochytrium mangrovei. J. Agric. Food Chem. 52:1196-1200.

Kang, H. C., Jeong, H. J., Ok, J. H., You, J. H., Jang, S. H., Lee, S. Y., Lee, K. H., Park, J. Y. \& Rho, J. -R. 2019. Spatial and seasonal distributions of the phototrophic dinoflagellate Biecheleriopsis adriatica (Suessiaceae) in Korea: quantification using qPCR. Algae 34:111-126.

Kang, N. S., Jeong, H. J., Moestrup, Ø., Lee, S. Y., Lim, A. S., Jang, T. Y., Lee, K. H., Lee, M. J., Jang, S. H., Potvin, É., Lee, S. K. \& Noh, J. H. 2014. Gymnodinium smaydae n. sp., a new planktonic phototrophic dinoflagellate from the coastal waters of western Korea: morphology and molecular characterization. J. Eukaryot. Microbiol. 61:182-203.

Kang, N. S., Kim, E. S., Lee, J. A., Kim, K. M., Kwak, M. S., Yoon, M. \& Hong, J. W. 2020. First report of the dinoflagellate genus Effrenium in the east sea of Korea: morphological, genetic, and fatty acid characteristics. Sustainability 12:3928.

Khan, M. I., Shin, J. H. \& Kim, J. D. 2018. The promising future of microalgae: current status, challenges, and optimization of a sustainable and renewable industry for biofuels, feed, and other products. Microb. Cell Fact. 17:36.

Kim, S., Kang, Y. G., Kim, H. S., Yih, W., Coats, D. W. \& Park, M. G. 2008. Growth and grazing responses of the mixotrophic dinoflagellate Dinophysis acuminata as functions of light intensity and prey concentration. Aquat. Microb. Ecol. 51:301-310.

LaJeunesse, T. C., Parkinson, J. E., Gabrielson, P. W., Jeong, H. J., Reimer, J. D., Voolstra, C. R. \& Santos, S. R. 2018. Systematic revision of Symbiodiniaceae highlights the antiquity and diversity of coral endosymbionts. Curr. Biol. 28:2570-2580.

Lee, B. I., Kim, S. K., Kim, J. H., Kim, H. S., Kim, J. I., Shin, W., Rho, J. -R. \& Yih, W. 2019a. Intraspecific variations in macronutrient, amino acid, and fatty acid composition 
of mass-cultured Teleaulax amphioxeia (Cryptophyceae) strains. Algae 34:163-175.

Lee, K. H., Jeong, H. J., Jang, T. Y., Lim, A. S., Kang, N. S., Kim, J. -H., Kim, K. Y., Park, K. -T. \& Lee, K. 2014. Feeding by the newly described mixotrophic dinoflagellate Gymnodinium smaydae: feeding mechanism, prey species, and effect of prey concentration. J. Exp. Mar. Biol. Ecol. 459:114-125.

Lee, K. H., Jeong, H. J., Kang, H. C., Ok, J. H., You, J. H. \& Park, S. A. 2019b. Growth rates and nitrate uptake of cooccurring red-tide dinoflagellates Alexandrium affine and $A$. fraterculus as a function of nitrate concentration under light-dark and continuous light conditions. Algae 34:237-251.

Leu, S. \& Boussiba, S. 2014. Advances in the production of high-value products by microalgae. Ind. Biotechnol.10:169-183.

Li, A., Stoecker, D. K. \& Adolf, J. E. 1999. Feeding, pigmentation, photosynthesis and growth of the mixotrophic dinoflagellate Gyrodinium galatheanum. Aquat. Microb. Ecol. 19:163-176.

Li, X., Xu, H. \& Wu, Q. 2007. Large-scale biodiesel production from microalga Chlorella protothecoides through heterotrophic cultivation in bioreactors. Biotechnol. Bioeng. 98:764-771.

Liang, Y., Sarkany, N., Cui, Y., Yesuf, J., Trushenski, J. \& Blackburn, J. W. 2010. Use of sweet sorghum juice for lipid production by Schizochytrium limacinum SR21. Bioresour. Technol. 101:3623-3627.

Lim, A. S., Jeong, H. J., Kim, S. J. \& Ok, J. H. 2018. Amino acids profiles of six dinoflagellate species belonging to diverse families: possible use as animal feeds in aquaculture. Algae 33:279-290.

Lim, A. S., Jeong, H. J. \& Ok, J. H. 2019a. Five Alexandrium species lacking mixotrophic ability. Algae 34:289-301.

Lim, A. S., Jeong, H. J., Ok, J. H., You, J. H., Kang, H. C. \& Kim, S. J. 2019b. Effects of light intensity and temperature on growth and ingestion rates of the mixotrophic dinoflagellate Alexandrium pohangense. Mar. Biol. 166:98.

Mansour, M. P., Frampton, D. M. F., Nichols, P. D., Volkman, J. K. \& Blackburn, S. I. 2005. Lipid and fatty acid yield of nine stationary-phase microalgae: applications and unusual $\mathrm{C}_{24}-\mathrm{C}_{28}$ polyunsaturated fatty acids. J. Appl. Phycol. 17:287-300.

Martins, D. A., Custódio, L., Barreira, L., Pereira, H., BenHamadou, R., Varela, J. \& Abu-Salah, K. M. 2013. Alternative sources of $n$-3 long-chain polyunsaturated fatty acids in marine microalgae. Mar. Drugs 11:2259-2281.

Mendes, A., Reis, A., Vasconcelos, R., Guerra, P. \& da Silva, T. L. 2009. Crypthecodinium cohnii with emphasis on DHA production: a review. J. Appl. Phycol. 21:199-214.

Mobin, S. \& Alam, F. 2017. Some promising microalgal species for commercial applications: a review. Energy Procedia 110:510-517.

Ning, Y. \& Liu, X. 2020. Enteromorpha hydrolysate as carbon source for fatty acids production of microalgae Schizochytrium sp. Energy 203:117900.

Onodera, K., Konishi, Y., Taguchi, T., Kiyoto, S. \& Tominaga, A. 2014. Peridinin from the marine symbiotic dinoflagellate, Symbiodinium sp., regulates eosinophilia in mice. Mar. Drugs 12:1773-1787.

Paliwal, C., Mitra, M., Bhayani, K., Bharadwaj, S. V. V., Ghosh, T., Dubey, S. \& Mishra, S. 2017. Abiotic stresses as tools for metabolites in microalgae. Bioresour. Technol. 244:1216-1226.

Park, W. -K., Moon, M., Shin, S. -E., Cho, J. M., Suh, W. I., Chang, Y. K. \& Lee, B. 2018. Economical DHA (docosahexaenoic acid) production from Aurantiochytrium sp. KRS101 using orange peel extract and low cost nitrogen sources. Algal Res. 29:71-79.

Patil, V., Källqvist, T., Olsen, E., Vogt, G. \& Gislerød, H. R. 2007. Fatty acid composition of 12 microalgae for possible use in aquaculture feed. Aquac. Int. 15:1-9.

Pleissner, D. \& Eriksen, N. T. 2012. Effects of phosphorous, nitrogen, and carbon limitation on biomass composition in batch and continuous flow cultures of the heterotrophic dinoflagellate Crypthecodinium cohnii. Biotechnol. Bioeng. 109:2005-2016.

Rawat, I., Kumar, R. R., Mutanda, T. \& Bux, F. 2013. Biodiesel from microalgae: a critical evaluation from laboratory to large scale production. Appl. Energy 103:444-467.

Shimizu, Y. 1996. Microalgal metabolites: a new perspective. Annu. Rev. Microbiol. 50:431-465.

Stoecker, D. K., Hansen, P. J., Caron, D. A. \& Mitra, A. 2017. Mixotrophy in the marine plankton. Ann. Rev. Mar. Sci. 9:311-335.

Tan, C. H., Show, P. L., Chang, J. -S., Ling, T. C. \& Lan, J. C. -W. 2015. Novel approaches of producing bioenergies from microalgae: a recent review. Biotechnol. Adv. 33:12191227.

Tang, E. P. Y. 1996. Why do dinoflagellates have lower growth rates? J. Phycol. 32:80-84.

Taylor, F. J. R., Hoppenrath, M. \& Saldarriaga, J. F. 2008. Dinoflagellate diversity and distribution. Biodivers. Conserv. 17:407-418.

Thomas, W. H. \& Gibson, C. H. 1990. Effects of small-scale turbulence on microalgae. J. Appl. Phycol. 2:71-77.

Thompson, P. A., Guo, M. -X., Harrison, P. J. \& Whyte, J. N. C. 1992. Effects of variation in temperature. II. On the fatty acid composition of eight species of marine phyto- 
plankton. J. Phycol. 28:488-497.

Torres-Tiji, Y., Fields, F. J. \& Mayfield, S. P. 2020. Microalgae as a future food source. Biotechnol. Adv. 41:107536.

Volkman, J. K., Jeffrey, S. W., Nichols, P. D., Rogers, G. I. \& Garland, C. D. 1989. Fatty acid and lipid composition of 10 species of microalgae used in mariculture. J. Exp. Mar. Biol. Ecol. 128:219-240.

Wang, S., Chen, J., Li, Z., Wang, Y., Fu, B., Han, X. \& Zheng, L. 2015. Cultivation of the benthic microalga Prorocentrum lima for the production of diarrhetic shellfish poisoning toxins in a vertical flat photobioreactor. Bioresour. Technol. 179:243-248.

Yongmanitchai, W. \& Ward, O. P. 1991. Growth of and ome- ga-3 fatty acid production by Phaeodactylum tricornutum under different culture conditions. Appl. Environ. Microbiol. 57:419-425.

Yoo, Y. D., Jeong, H. J., Kim, M. S., Kang, N. S., Song, J. Y., Shin, W., Kim, K. Y. \& Lee, K. 2009. Feeding by phototrophic red-tide dinoflagellates on the ubiquitous marine diatom Skeletonema costatum. J. Eukaryot. Microbiol. 56:413-420.

You, J. H., Jeong, H. J., Lim, A. S., Ok, J. H. \& Kang, H. C. 2020. Effects of irradiance and temperature on the growth and feeding of the obligate mixotrophic dinoflagellate Gymnodinium smaydae. Mar. Biol. 167:64. 